main mechanisms for the integration of universities and the motives for the admission of Hong Kong applicants to universities in Mainland China. Despite the ambiguous attitude of Hong Kong residents to the policies of the central government, the process of integration in education is bilateral.

Keywords: PR China, Hong Kong, higher education, integration, educational policy

АРШИН Константин Валерьевич - ученый секретарь Федерального исследовательского центра картофеля им. А.Г. Лорха (140051, Россия, Московская обл., г. Люберцы, пос. Красково, ул. Лорха, 23B; Kosta-10@yandex.ru)

\title{
ПОЛИТИКА УПРАВЛЕНИЯ МИГРАЦИЕЙ В КНР
}

\begin{abstract}
Аннотация. В течение последних нескольких десятилетий Китай демонстрирует значительный экономический рост. Многие эксперты справедливо связывают его с либерализацией китайской экономики, а также политикой открытых дверей, которая обеспечивает КНР инвестициями. Однако вне поля внимания оказывается миграционная политика, также внесшая существенный вклад в развитие страны. В статье предпринята попытка комплексного рассмотрения эволюции китайской миграционной системы с момента образования КНР в 1949 г. В рамках проведенного анализа автор отмечает как сильные стороны миграционной политики Китая, так и ее недостатки, препятствующие увеличению миграционного потока.
\end{abstract}

Ключевые слова: миграция, Китай, визы, трудовые мигранты, беженцы, дифференциация

B настоящее время Китай, будучи одной из наиболее стремительно развивающихся стран мира, характеризуется развертыванием крайне динамичных миграционных процессов. О масштабах этих процессов можно судить, например, по объемам миграционного обмена Китая с другими странами. В частности, в 2015 г. «численность китайских мигрантов, выехавших из Китая в другие страны, составила более 273 млн чел., а число иностранцев, прибывших в Китай - 76,31 млн чел.» [Сюнь Ю 2018: 132]. Очевидно, что подобные миграционные потоки оказывают существенное влияние на экономическое и социально-политическое развитие как Азиатского региона, так и всего мира.

Однако необходимо отметить, что указанная ситуация характерна исключительно для Китая XXI в. В течение длительного периода страна проводила политику закрытых дверей, всячески ограничивая миграцию и, более того, препятствуя нахождению на своей территории иностранцев. Впервые ограничения на пребывание иностранцев в стране были введены в 1951 г. Временными действующими правилами контроля за въездом в страну и выездом из страны, также проживанием в стране иностранцев-резидентов. Эти правила ограничивали для иностранцев получение разрешения на посещение Китая, а в случае, если такое разрешение было предоставлено, устанавливали правила контроля за подобными иностранцами. Впоследствии вплоть до 1977 г. указанные правила периодически переутверждались в разных нормативных правовых актах. Так, в 1954 г. были приняты Временные меры по управлению въездом в страну и выездом из страны иностранцев-резидентов, в том же году утверждены Временные правила выдачи виз и регистрации прибывающих иностранцев и Временные правила путешествия иностранцев. В 1964 г. приняты Правила управления въездом в страну и выездом из страны, транзитом, пребыванием и путешествием иностранцев. 
Начало экономических реформ в 1978 г., успешная реализация которых потребовала привлечения высококвалифицированных специалистов и инвестиций, ознаменовалось значительным пересмотром основ миграционной политики. В первую очередь изменению подверглись положения, ограничивающие пребывание в стране иностранных высококвалифицированных специалистов или, как они именовались в официальных документах, «иностранных культурно-просветительских специалистов». Впервые данное понятие было определено в Испытательных положениях об иностранных культурнопросветительских специалистах 1980 г.: «иностранный гражданин, нанятый китайскими вузами, пропагандистскими, издательскими, культурно-художественными, медицинскими и спортивными учреждениями и получающий государственные льготы или вознаграждения» 1 . Впоследствии был принят еще ряд нормативных документов, касающихся способов отбора, поддержки и адаптации высококвалифицированных специалистов, таких как Временные положения по привлечению иностранных специалистов (1983 г.), Методы стимулирования иностранных специалистов (1990 г.), Методы управления иностранными инвестициями и иностранными специалистами (1996 г.). В 2002 г. канцелярией Госсовета Китая была подготовлена программа «Планирование и подготовка персонала специалистов в 2002-2005 гг.», где были перечислены сферы, нуждающиеся в привлечении иностранных специалистов. К таковым были отнесены информационно-техническая, биологическая, материальнотехническая, авиакосмическая, финансовая, юридическая сферы, международная торговля и менеджмент.

Важно отметить, что очевидная потребность в иностранных высококвалифицированных работниках сочеталась с трудностями по их привлечению на постоянное место жительства в Китай вследствие существования бюрократических препон, делавших возможность долгосрочного пребывания иностранных работников в Китае практически недостижимой. Характерным примером подобных препон может служить казус с рабочими визами $(Z)$.

Данный тип виз был введен Подробными правилами осуществления Закона о контроле за въездом в страну и выездом из страны иностранцев в 1986 г. Указанные правила должны были конкретизировать положения принятого годом раньше закона «О контроле за въездом в страну и выездом из страны иностранцев», который устанавливал следующие категории прибывающих в Китай иностранцев: прибывшие для «долгосрочного проживания», «краткосрочного проживания», «постоянного проживания». Соответственно, для указанных категорий иностранцев Подробные правила вводили следующие типы виз: для постоянного проживания $(D)$, рабочая $(Z)$, учебная $(X)$, деловая $(F)$, туристическая $(L)$, транзитная $(G)$ визы, виза для членов экипажа $(C)$ и приграничная виза. Однако Положение об управлении трудоустройством иностранцев, которое регламентировало выдачу виз $Z$, а также саму процедуру трудоустройства иностранцев, было принято только 10 лет спустя, в 1996 г. Вследствие этого, с одной стороны, эффект от разнообразных программ по привлечению высококвалифицированных специалистов оказался не столь сильным, как ожидалось. Так, с 1985 по 2004 г. только чуть более 3000 высококвалифицированных специалистов получили право на временное проживание в Китае, и лишь 50 чел. - право на постоянное проживание. С другой стороны, Китай столкнулся с проблемой нелегальной миграции, поскольку в связи с отсутствием правил по выдаче визы $Z$ значительное число иностранцев вынуждены были

1 Положение об испытании иностранных культурно-просветительных специалистов [Сюнь Ю 2018: 133]. 
прибегать к нелегальному трудоустройству. В качестве примера масштабности проблемы необходимо указать, что в период с 1995 по 2006 г. органы общественной безопасности депортировали 79 тыс. незаконных иностранных мигрантов. При этом только за 2006 г. депортации подверглись 16 тыс. мигрантов.

Поиск решения указанных проблем (привлечение высококвалифицированных специалистов и борьба с нелегальной миграцией) лег в основу стратегии миграционной политики, реализуемой Китаем с 2004 г. Так, в 2004 г. было опубликовано новое Положение о регулировании выдачи иностранным лицам вида на жительство в Китае. Оно устанавливало категории иностранных граждан, которые имели право претендовать на вид на жительство. К таковым Положение относило высококвалифицированных специалистов, работавших на концессионных предприятиях; крупных зарубежных инвесторов; лиц, внесших вклад в развитие страны; членов воссоединяющихся семей. Эффект от изменения условий получения вида на жительство стал очевиден уже через год, когда общее число иностранцев, имеющих вид на жительство, достигло 649 тыс. чел.

В 2012 г. был опубликован Перечень прав и социального обеспечения, предоставляемых иностранцам, имеющим вид на жительство в Китае, уравнивающий в правах и обязанностях граждан Китая и иностранцев, проживавших по виду на жительство. В этом же году был принят новый закон «О контроле за въездом в страну и выездом из страны иностранцев», который значительной расширял список возможных виз, в т.ч. в сторону обеспечения более комфортного проживания в стране иностранных специалистов. Так, были введены виза специалиста $(R)$ и гостевая виза для родственников иностранца, работающего иди проживающего в Китае, $(S)$.

Решение проблемы нелегальной миграции Китай реализует с помощью заключения двусторонних договоров о борьбе с незаконной миграцией. По состоянию на 2015 г. было заключено более 40 таких договоров, в т.ч. со странами ЕС, США, Россией, рядом государств - членов СНГ. Также в качестве эффективного метода борьбы с нелегальными мигрантами рассматривается административная ответственность. Например, уже упоминавшийся закон «О контроле за въездом в страну и выездом из страны иностранцев» 2012 г. предусматривает штраф для нелегальных мигрантов в размере 10 тыс. юаней или административный арест на 15 суток. Для мигранта, осуществляющего нелегальную трудовую деятельность, предусмотрен штраф в размере 20 тыс. юаней. Граждане Китая в соответствии с законом обязаны уведомлять об известных им нелегальных мигрантах органы общественной безопасности. Если нелегальный мигрант не способен заплатить за депортацию, то в качестве наказания используется длительное заключение [Балданов 2018]. Кроме того, в ряде регионов, где отмечается концентрация нелегальных мигрантов, часто проводятся спецоперации, направленные на выявление нелегальных мигрантов и пресечение каналов такой миграции.

В свете изложенного характерно отношение китайских властей к беженцам и жертвам нелегальной торговли людьми. Несмотря на тот факт, что Китай в 1951 г. ратифицировал Конвенцию о статусе беженцев, соответствующий Протокол - в 1967 г., а также Протокол ООН о предупреждении и пресечении торговли людьми - в 2009 г., положения о беженцах появились только в законе «О контроле за въездом в страну и выездом из страны иностранцев» 2012 г., а статус жертв торговли людьми так до сих пор законодательно не урегулирован.

Приведенный выше краткий анализ демонстрирует, что миграционная политика Китая не может быть названа по-настоящему зрелой и последовательной. Здесь следует выделить несколько причин. Во-первых, в Китае отсутствует 
специальный орган, ответственный за реализацию миграционной политики. В настоящее время указанные функции разделены между тремя ведомствами:

- Министерством общественной безопасности, отвечающим за вопросы въезда и выезда иностранцев;

- Министерством трудовых ресурсов и социального обеспечения, занимающимся проблемами социального обеспечения и трудоустройства иностранцев;

- Бюро по делам иностранных специалистов, реализующим политику по привлечению в Китай высококвалифицированных специалистов.

Также эпизодически в реализацию миграционной политики вмешиваются канцелярия Госсовета по делам китайцев, проживающих за границей; Министерство коммерции; Министерство иностранных дел; Государственный комитет по развитию и реформам, а также ряд других ведомств. Несмотря на налаженное взаимодействие, данные органы зачастую дублируют административные функции друг друга, что оказывает негативное влияние на реализацию политики в сфере миграции.

Вторым обстоятельством, препятствующим достижению Китаем целей миграционной политики, в частности борьбы с нелегальной миграцией, следует назвать отсутствие единого закона, который бы регулировал все вопросы миграционной политики и определял бы вектор развития миграционной политики страны. Как следствие, положения миграционного законодательства устанавливаются провинциями страны самостоятельно. Это следует рассматривать в качестве основной причины того, почему в разных провинциях Китая миграционная политика существенным образом отличается. В качестве примера можно привести различие ситуации в г. Гуанчжоу и в соседнем с ним районе Фошань. В то время как в первом действуют крайне жесткие правила в отношении нелегальных мигрантов (вплоть до трехмесячного тюремного заключения), во втором к нарушителям относятся достаточно лояльно.

Указанные факты, очевидно, свидетельствуют об отсутствии единого пространства реализации миграционной политики в Китае. Представляется, что именно фактор отсутствия единого пространства в осуществлении миграционной политики препятствует значительному увеличению миграционного потока в Китай в виде высококвалифицированных специалистов. Этот важный фактор производства мог бы внести вклад в увеличение темпов экономического роста страны, который в значительной степени подточен как развивающимся мировым экономическим кризисом, так и развернувшейся эпидемией $C O V I D-19$.

\section{Список литературы}

Балданов Р.А. 2018. Основные тенденции современной иммиграционной политики Китая. - Вестник Московского государственного областного универcumema. № 2. С. 20-28.

Сюнь Ю. 2018. Китайский опыт совершенствования миграционной политики: основные этапы, нерешенные проблемы. - Вестник Московского государственного областного университета. Сер. История и политические науки. № 5. C. 131-141. 
ARSHIN Konstantin Valerievich, Scientific Secretary of the Russian Potato Research Center (23B Lorcha St, Kraskovo, Lubertsy, Moscow Region, Russia, 140051; Kosta-10@yandex.ru)

\title{
PRC MIGRATION POLICY
}

\begin{abstract}
Over the last several decades, China showed significant economic growth. Many experts rightly associate it with the liberalization of the Chinese economy, as well as with the open door policy that provided the PRC with investments. However, migration policy, which also made a significant contribution to the development of the country, is out of the spotlight. The article attempts to consider the evolution of the Chinese migration system comprehensively since the formation of the PRC in 1949. The analysis highlights both the strengths of China's migration policy and its shortcomings that create obstacles to increasing the migration flow.

Keywords: migration, China, visas, labor migrants, refugees, differentiation
\end{abstract}

ЕРЕМЕЕВ Станислав Германович - доктор экономических наук, профессор; ректор Ленинградского государственного университета им. А.С. Пушкина (196605, Россия, Санкт-Петербург, г. Пушкин, Петербургское ш., 10; Eremeevsg.lengu.ru@gmail.com)

\section{ФИЛОСОФСКАЯ ПРОБЛЕМА ГАРМОНИЗАЦИИ ФОРМЫ И СОДЕРЖАНИЯ В СОВРЕМЕННЫХ ПРОЦЕССАХ УРБАНИЗАЦИИ (на примере китайских городов-призраков)}

Аннотация. В статье анализируется феномен китайских городов-призраков, характеризующихся малонаселенными и в основном незаселенными небоскребами, жилыми домами и грандиозными площадями. В работе поднимается философская проблема гармонизации формы и содержания, в т.ч. в современных процессах урбанизации. При этом готовый рецепт, алгоритм такой гармонизации отсутствует. Вместе с тем она может быть достигнута, если люди, ответственные за реализацию соответствующих проектов, находятся в постоянном тесном контакте с населением и гражданским обществом, вырабатывая совместные и компромиссные способы разрешения возникающих противоречий.

Автор делает вывод, что большая часть научной литературы, посвященной городам-призракам, либо использует описательный подход, либо сосредоточена на финансово-экономическом анализе. В то же время редко анализируются фундаментальные причины или процессы, в результате которых это явление возникло.

Ключевые слова: форма и содержание, формализация, город-призрак, урбанизация, социальная устойчивость

B современном процессе урбанизации отчетливо выявляется эволюционный характер. Это подтверждается такими присущими ему характеристиками, как многовекторность в выработке направлений развития, неоднозначность оценок, спонтанность, парадоксальным образом сочетающаяся с само собой разумеющимся моментом сознательного социального планирования. Наглядной иллюстрацией этого являются процессы урбанизации в Китае. В период с 1978 по 2012 гг. городское население Китая увеличилось с 12,9 до 52,6\% [Chen 2013: 26; Bai, Shi, Liu 2014: 159]. 